\title{
Erratum to: Behavioral Finance and Financial Literacy: Educational Implications of Biases in Financial Decision Making
}

\author{
Dirk Loerwald and Arne Stemmann
}

\section{Erratum to:}

\section{Chapter 3 in: C. Aprea et al. (eds.), International Handbook of Financial Literacy, DOI 10.1007/978-981-10-0360-8_3}

The original version of the book was inadvertently published with an incorrect title and sub-title in Chapter-3. The title is "Behavioral Finance and Financial Literacy" and the sub-title is "Educational Implications of Biases in Financial Decision Making".

The online version of the updated original chapter can be found under DOI 10.1007/978-981-10-0360-8_3

\section{Loerwald $(\bowtie)$}

Carl von Ossietzky Universität Oldenburg, Faklutät II, Informatik, Wirtschafts- und Rechtswissenschaften, Ökonomische Bildung, Ammerländer Heerstraße 114-118, 26129 Oldenburg, Germany

e-mail: dirk.loerwald@uni-oldenburg.de
A. Stemmann
Carl von Ossietzky Universität Oldenburg, Faklutät II, Informatik, Wirtschafts- und Rechtswissenschaften, Ökonomische Bildung, Oldenburg, Germany
e-mail: arne.stemmann@uni-oldenburg.de 